\title{
Review article \\ Quorum sensing related activity of Aggregatibacter actinomycetemcomitans in periodontal disease: A review
}

\author{
Haswati @ Nurhayati Abdullah ${ }^{1,2}$, Suharni Mohamad ${ }^{2}$, Wan Rohani WanTaib ${ }^{1}$, Norzawani Jaffar ${ }^{1}$ \\ ${ }^{1}$ Faculty of Health Sciences, Universiti Sultan Zainal Abidin (UniSZA), Gong Badak Campus, 21300 Kuala Terengganu, \\ Terengganu, Malaysia \\ ${ }^{2}$ School of Dental Sciences, Universiti Sains Malaysia, Health Campus, 16150 Kubang Kerian, Kelantan, Malaysia
}

(Received: January $2021 \quad$ Revised: April $2021 \quad$ Accepted: April 2021)

Corresponding author: Norzawani Jaffar. Email: zawanijaffar@unisza.edu.my

\begin{abstract}
Aggregatibacter actinomycetemcomitans is a significant pathogen in periodontal disease, contributing to aggressive and chronic inflammatory conditions of the periodontal area. This pathogen is shown to contribute to the tenacious biofilm formation in the oral cavity and results in persistent induction of pro-inflammatory response leads to progressive periodontitis. Besides the immune-modulatory capabilities, quorum sensing (QS) activity is believed to influence the virulence activities, leading to a progressive inflammatory response by the host. QS modulates the expression of genes involved in the processes related to survival and biofilm formation activities by answering the localized bacterial population's fluctuation. Understanding the QS activity of this pathogen and its impact on disease might be useful as an alternative approach to counteract the infection. Therefore, this review paper is focusing on the evaluation of the QS activities of A. actinomycetemcomitans and how this activity influences the progression of periodontal disease. Based on the previous findings, we found that there are possibilities the QS activity interrupted by enzymes or molecules that blocking the QS signals produced by other species of bacteria. However, due to minimal QS studies that have been done specifically on A. actinomycetemcomitans, the mechanism is not conclusive. Therefore, this might initiate an essential option for alternative treatment against periodontal pathogen infection and oral health care.
\end{abstract}

Keywords: Aggregatibacter actinomycetemcomitans; biofilm; periodontal disease; quorum sensing; auto-inducer.

\section{INTRODUCTION}

$\mathrm{P}^{\prime}$ eriodontal disease is one of the grave global public health concerns. A high prevalence of periodontal disease has been reported in both developed and developing countries, which affects around $20-50 \%$ of the worldwide population (1). It is characterized by a chronic inflammatory condition of the periodontium area, which leads to loss of periodontal ligament and destruction of surrounding alveolar bone. Periodontal disease is considered one of the two most significant threats to oral health besides dental caries, and it is the leading cause of tooth loss. The significant cause of periodontal disease is due to poor or ineffective oral hygiene, improper tooth brushing techniques, and failure to carry out regular interdental cleaning, which leads to dental plaque.

Dental plaque formation is initiated by the adherence of the bacterial cells on the periodontium area's tooth surfaces and later developing the matured biofilm. This activity leads to periodontitis, which includes swelling of the gingival, redness and bleeding from the gums, the spacing between teeth, loose teeth, and finally, loss of bone around the teeth. Besides, periodontal disease also has a potential risk to other systemic disorders. This is crucial since numbers of findings reported the linkage of oral diseases with many non-oral and systemic diseases, such as cancer, cardiovascular disease, type 2 diabetes, respiratory tract infection, adverse pregnancy outcomes, and neurodegenerative disease.

Predominantly, the etiologic agents of periodontal disease are Gram-negative anaerobic bacteria. Most of the highlighted bacteria are $A$. actinomycetemcomitans, Porphyromonas gingivalis, Prevotella intermedia, Bacteriodes forsythus, Campylobacter rectus, Eubacterium nodatum, Peptostreptococcus micros, Streptococcus intermedius, and Treponema sp. This finding supports the report in 1975, which highlighted $A$. actinomycetemcomitans as the first bacteria identified as a possible periodontal pathogen of localized aggressive periodontitis (LAP) (2). In agreement, most cross-sectional studies reported that most periodontal disease cases in adolescents are highly related to A. actinomycetemcomitans (3).

Thus, this review highlights $A$. actinomycetemcomitans as a significant pathogen in periodontal disease. In addition, $A$. actinomycetemcomitans shows many virulence factors with differential capabilities, enabling it to colonize the oral cavity consistently, modulate host immune system, invade periodontal tissues, initiate connective tissue destruction, and interrupt tissue healing (4). Other than that, the oral disease's pathogenesis is also reported related to the periodontal pathogens' QS activity in the oral cavity. The development of biofilm in caries or plaques formation might suggest the need 
for cell-cell communication or QS to regulate the attachment and biofilm activities. Thus, suggesting the impact of QS on the bacterial biofilm formation and virulence activity. Therefore, this review paper emphasizes the QS related activity of $A$. actinomycetemcomitans and their contribution to periodontal disease. To date, there is lack understanding of the specific mechanism in a periodontal disease process that involves a dominant role of the periodontal pathogen. This review might help to understand the influence of QS in $A$. actinomycetemcomitans toward the development or progression of a periodontal disease.

\section{Aggregatibacter actinomycetemcomitans}

A. actinomycetemcomitans is a Gram-negative, capnophilic non-motile, facultative anaerobic bacillus that significant to cause progressive form of periodontal disease such as LAP. Previously, this organism has been known as Actinobacillus actinomycetemcomitans. However, in 2006, this organism was reclassified as $A$. actinomycetemcomitans (5). This species is reported as five serotypes (a-e), with more than one serotype can be found in the mouth of an individual (6). The serotypes of this species are based on the structural differences on the O-antigen part on lipopolysaccharide (LPS).

\section{The pathogenicity properties of A. actinomycetemcomitans}

The pathogenicity to the oral cavity is due to several virulence factors such as leukotoxin which can destroy host immune tissues and the cytolethal distending toxin (CDT) which disrupts the macrophage functions by preventing the phagocytic activity (7). The CDT family comprises a number of bacterial protein exotoxin express by Gram-negative species. Interestingly, A. actinomycetemcomitans is the only known oral species with this property. The CDT mechanism is by causing the DNA damage, cell cycle arrest, and apoptosis of the intoxicated cells. Besides, the LPS of A. actinomycetemcomitans is a potent proinflammatory mediator, induce apoptosis in BeWo cells (8), and can increase the inducible nitric oxide synthase (iNOS) activity production by human osteoblast-like cell line (9) which leads to bone resorption. In addition, A. actinomycetemcomitans LPS was reported to induce the production of neutrophil reactive oxygen species (ROS) to a greater extent compared to $P$. gingivalis and $P$. intermedia (10). This variety of virulence factors play an essential role in periodontal disease's pathogenesis either directly or indirectly. Several virulence factors can cause cell death and induce the host inflammatory response. Factors that directly destroy the periodontal tissues involve infections on the gingival connective tissue, epithelium, and periodontal pocket, while the virulence factors that indirectly affect the periodontal tissues essentially act on the host immune response.
Both direct and indirect effect contributes to progressive destruction of the periodontal tissue.

\section{Quorum sensing}

Quorum sensing (QS) is a biological process by which bacteria can communicate and modulating the expression of genes involved in processes related to survival, biofilm formation, acid tolerance, virulence, and pathogenicity (11). QS was known as communication between cells. The activity involves controlling the bacterial gene expression according to population cell density. Bacteria produce and secrete small signaling molecules known as autoinducers. The concentration of this molecule increases as a function of population cell density. A change in gene expression occurs as soon as the stimulatory threshold is reached (12). In the QS system, the bacteria must consist of three characteristics; capability to secrete signaling molecules, the possibility to detect the concentration changes in signaling molecules, and the ability to regulate gene transcription as the results of QS (13). This process is dependent on the diffusion mechanism of the signaling molecules. QS signaling molecules are usually secreted at a low level at the planktonic level. At low cell density, the molecules may just diffuse away. At high cell density, the signaling molecules' local concentration may exceed its threshold level and trigger gene expression changes (14).

\section{Categories of QS system}

Gram-positive and Gram-negative bacteria possess different categories of QS systems. In general, bacteria can communicate both within their species and between species. For intra-species communication, Gram-positive bacteria use species-specific, small autoinducing peptides (AIP) as signaling molecules (15). Whereas, Gramnegative bacteria use acylated homoserine lactones (AHLs) or also called autoinducer-1 (AI-1), as species-specific QS signals (16). For inter-species exchanges, they use an autoinducer-2 (AI-2) QS system, called the universal language of the bacteria (12).

Among those signal molecules, (AHLs in Gramnegative bacteria has been chosen for extensive research and become a standard for bacteria intercellular signaling. These AHLs have their specific structure and only a small amount in the bacteria population. The communication between bacteria mediated through the AHL signaling QS system allows them to coordinate virulence expression and biofilm formation. However, this communication is inhibited by disrupting the receptor binding process. Small changes during the attachment of AHL acyl side chain or lactone ring or both to the receptor protein may cause no signal generation and communication disable (17). Another vital signal molecule in bacterial communication is AI-2. AI-2-mediated QS signaling 
pathways have been reported to be able to control physiological behavior and gene expression of bacteria. Autoinducers are produced in response to cell-population density, which reaches a threshold level and begins to initiate changes in the bacteria through its receptors' activation and binding (18).

\section{Quorum sensing related activity in Aggregatibacter actinomycetemcomitans}

Though Gram-negative bacteria communicate with each other by producing signal molecules called AHLs. Interestingly, most of the QS reports for $A$. actinomycetemcomitans emphasize the production of AI-2 as it signaling molecules. This was supported by Bachtiar and the team, which mentioned that the only identified signaling molecules in $A$. actinomycetemcomitans are AI-2 (19). Table 1 shows a few QS related activity in $A$. actinomycetemcomitans.

Table 1: The Quorum sensing related activity in A. actinomycetemcomitans (Aa) strains

\begin{tabular}{|c|c|c|c|c|}
\hline Strains & Description & $\begin{array}{c}\text { QS } \\
\text { molecules }\end{array}$ & $\begin{array}{c}\text { Identified } \\
\text { genes }\end{array}$ & Reference \\
\hline $\begin{array}{c}\text { Aa JP2 } \\
\text { Aa } 652 \\
\text { Aa ATCC } 29524 \\
\text { Aa } \mathrm{HK} 890 \\
\text { Aa } \mathrm{HK} 905 \\
\text { Aa Fambo } \\
\text { Aa } \text { Emory }\end{array}$ & $\begin{array}{l}\text { A. actinomycetemcomitans expresses } \operatorname{luxS} \text { and secretes a } \\
\text { signal related to AI- } 2 \text { of } V \text {. harveyi. } \\
\text { AI- } 2 \text { levels peaked in cultures of } A \text {. } \\
\text { actinomycetemcomitans at mid-exponential-phase and } \\
\text { were significantly reduced in cultures at late-log- and } \\
\text { stationary-phases. } \\
\text { luxS induce leukotoxin expression and periplasmic } \\
\text { transport protein, which involves in the iron acquisition. }\end{array}$ & $\begin{array}{l}\text { AI-2-like } \\
\text { signal }\end{array}$ & $\begin{array}{l}\text { Homolog } \\
\text { of } V . \\
\text { harveyi } \\
\text { luxs }\end{array}$ & (20) \\
\hline $\begin{array}{c}A a \text { 4A259 } \\
\text { A } a \text { 4A52 } \\
\text { A } a \text { ATCC } 33384\end{array}$ & $\begin{array}{l}\text { None of the strains of } A \text {. actinomycetemcomitans } \\
\text { produce any of the AI-1, and AI-2 molecules tested. }\end{array}$ & N/A & N/A & (21) \\
\hline $\begin{array}{c}A a \mathrm{JP} 29 \\
A a \mathrm{JP} 2-12 \\
A a \mathrm{JP} 2-750 \\
A a \mathrm{JP} 2 \operatorname{arcB} 1 \\
\text { Aa JP2 } \operatorname{arcB} 1 \mathrm{YGS}\end{array}$ & $\begin{array}{l}\text { luxS is responsible for the production of autoinducer } 2 \\
\text { (AI-2). } \\
\text { Inactivation of luxS in A. actinomycetemcomitans JP2 } \\
\text { leads to reduced growth of the mutant, but not the wild- } \\
\text { type organism, under aerobic, iron-limited conditions. } \\
\text { AI-2 effects the expression of genes involved in the } \\
\text { acquisition and storage of iron. }\end{array}$ & AI-2 & $\begin{array}{l}\operatorname{luxS} \\
\text { Gene }\end{array}$ & (23) \\
\hline Aa JP2 & $\begin{array}{l}\text { Autoinducer } 2 \text { (AI-2) is required to grow } A \text {. } \\
\text { actinomycetemcomitans in culture under conditions of } \\
\text { iron limitation. } \\
\text { Biofilm growth of the luxS mutant exhibited lower total } \\
\text { biomass, and biofilm depth compared to the wild type } \\
\text { strain. } \\
\text { Normal biofilm growth of the luxS mutant was restored } \\
\text { genetically by introducing a functional copy of luxS and } \\
\text { biochemically by partially purifying AI- } 2 \text {. } \\
\text { A lack of biofilm growth was observed upon inactivation } \\
\text { of the RbsB and LsrB proteins, and wild-type biofilm } \\
\text { growth was reduced in the presence of ribose, which } \\
\text { competes with AI-2 for binding to RbsB }\end{array}$ & AI-2 & $\begin{array}{l}\operatorname{luxS} S \\
\text { Gene }\end{array}$ & (24) \\
\hline
\end{tabular}

Periodontal pathogens use QS to regulate their biofilm formation, iron uptake, stress response, and virulence factor expression (12). The AI-2 QS circuit in oral streptococcal species enables the inter-species communication in complex bacterial communities of the oral cavity $(20,21)$. In addition, $A$. actinomycetemcomitans involve directly triggers the expression of the QS regulon in cariogenic streptococci, Streptococcus mutans (22).

The luxS gene (19) with two periplasmic AI-2 receptors, LsrB and RbsB protein play important role in the production of AI-2 in $A$. actinomycetemcomitans. Besides, the system involved managing the expression of virulence factors, biofilm formation, iron uptake, and stimulating the planktonic growth of the organism under conditions of iron limitation $(23,24)$.
Table 1: The Quorumsensi 


\begin{tabular}{|c|c|c|c|c|}
\hline $\begin{array}{c}A a 652 \text { (wild } \\
\text { type, mutant) } \\
A a \mathrm{JP} 2 \\
A a \mathrm{JP} 2-12 \\
\text { Aa JP2-12/750 }\end{array}$ & $\begin{array}{l}\text { Biofilm formation by the periodontal pathogen } \\
\text { Aggregatibacter actinomycetemcomitans depends on AI- } \\
2 \text { mediated QS. } \\
\text { QseBC two-component system is part of the AI-2 } \\
\text { regulon. There may be a link between the detection of } \\
\text { AI- } 2 \text { and the regulation of downstream cellular processes } \\
\text { involved in } A \text {. actinomycetemcomitans's biofilm } \\
\text { formation and virulence of. AI- } 2 \text { induces the expression } \\
\text { of } Q s e B C \text { in } A \text {. actinomycetemcomitans, and this } \\
\text { induction requires AI- } 2 \text { receptors, LsrB and BsrB. } \\
\text { Inactivation of qseC resulted in reduced biofilm growth. } \\
\text { qse } C \text { mutant induced significantly less alveolar bone } \\
\text { resorption than the wild type strain } \\
\text { AI- } 2 \text { also regulates the expression of } q s e C \text {, which in turn } \\
\text { contributes to biofilm growth and controls the expression } \\
\text { of at least some of the AI-2-regulated iron acquisition } \\
\text { genes. } \\
\text { Complementing } q s e C \text { with a plasmid-borne copy of } q s e C \\
\text { increased biomass and surface coverage to levels similar } \\
\text { to wild-type }\end{array}$ & AI-2 & $\begin{array}{l}\text { QseBC } \\
\text { gene } \\
\text { RbsB and } \\
\text { LsrB : } \\
\text { Protein }\end{array}$ & (25) \\
\hline Aa Y4 & $\begin{array}{l}\text { AI-2 Inhibits } C \text {. albicans hypha and biofilm formation. } \\
\text { A. actinomycetemcomitans adhered to } C \text {. albicans and } \\
\text { inhibited biofilm formation byAI-2 secreted during } \\
\text { growth. Biofilm formation of } C \text {. albicans increased } \\
\text { significantly when cultured with the luxS mutant of } A \text {. } \\
\text { actinomycetemcomitans, which lacked AI-2 production. } \\
\text { Wild-type-derived spent medium or synthetic AI-2 to } \\
\text { spent medium of the luxS strain restored the inhibition of } \\
\text { C. albicans biofilm formation to wild-type levels. } \\
\text { AI- } 2 \text { of } \text { A. actinomycetemcomitans is synthesized by } \\
\text { luxS, accumulates during growth, and inhibits } C \text {. } \\
\text { albicans hypha- and biofilm formation. }\end{array}$ & AI-2 & $\begin{array}{l}\text { luxS } \\
\text { Gene }\end{array}$ & (19) \\
\hline- & $\begin{array}{l}\text { The ability of } A \text {. actinomycetemcomitans to grow in } \\
\text { biofilm is closely linked to the AI-2 QS system. } \\
\text { A luxS gene mutant (no AI-2 synthase) can form a } \\
\text { mature biofilm, but the biofilm contains significantly less } \\
\text { biomass. } \\
\text { If exogenous autoinducer-2 or a functional luxS gene } \\
\text { carrying plasmid is added to the growth medium, the } \\
\text { average growth of the biofilm is restored. }\end{array}$ & AI-2 & $\begin{array}{l}\text { luxs } \\
\text { Gene }\end{array}$ & (12) \\
\hline $\begin{array}{l}\text { Aa UI-09 (wild } \\
\text { type strain) } \\
\text { Aa UI-09 luxS } \\
\text { (deletion mutant } \\
\text { strain) } \\
\text { Aa ATCC } 43718 \\
\text { (Y4) strains }\end{array}$ & $\begin{array}{l}\text { AI-2-containing spent media derived from } A \text {. } \\
\text { actinomycetemcomitans can reduce the biofilm biomass } \\
\text { of } C \text {. albicans without significantly inhibiting the } \\
\text { survival rate of } S \text {. mutans. } \\
\text { This process may explain that AI- } 2 \text { involvement help } \\
\text { maintains equilibrium or symbiotic relationships } \\
\text { between } C \text {. albicans and } S \text {. mutans in the oral ecosystem. }\end{array}$ & AI-2 & $\begin{array}{l}\text { luxS } \\
\text { Gene }\end{array}$ & (26) \\
\hline $\begin{array}{l}\text { Aa } 652 \text { (serotype } \\
\text { c) } \\
652-J R 25 \\
652-J R 37 \\
652-J R 38 \\
652-J R 39 \\
652-J R 23\end{array}$ & $\begin{array}{l}\text { ygiW and qseBC are co-expressed in } A \text {. } \\
\text { actinomycetemcomitans and regulate biofilm growth } \\
\text { The sensor domain of QseC and a functional YgiW } \\
\text { protein regulate biofilm growth of } A \text {. } \\
\text { actinomycetemcomitans by: in-frame deletion in ygiW } \\
\text { had a minor effect on biofilm depth but caused a great } \\
\text { increase in the surface coverage relative to the wild-type. } \\
\text { The } \\
\text { deletion of the periplasmic sensor domain of QseC } \\
\text { resulted in a significant reduction in biofilm depth, } \\
\text { biomass, and surface coverage, suggesting that the } \\
\text { sensor domain is essential for optimal biofilm formation } \\
\text { of A. actinomycetemcomitans. }\end{array}$ & & $\begin{array}{c}y g i W \text { and } \\
q s e B C\end{array}$ & (27) \\
\hline
\end{tabular}

The localization of A. actinomycetemcomitans at the periodontium area initiates by the bacterial attachment and biofilm formation, mediated through the AI-2 QS system (25). The QseBC two-component signal transduction system in this species is reported as associated with QS. It can be activated by a combination of epinephrine/norepinephrine and iron at the QseC adrenergic receptor (28). This activity 
seemly important in A. actinomycetemcomitans since the inactivation of $Q s e C$ influences the biofilm formation (25).

From the reported observation, biofilm growth was either reduced or completely disabled if one or both receptors were inactivated. It seems that each receptor interacts with the AI-2 at both low or high cell density, and this is suggesting that A. actinomycetemcomitans can act on both lower and higher AI-2 concentrations (24). This finding supports studies showing that the addition of ribose derivatives to the culture medium negatively affects $A$. actinomycetemcomitans biofilm formation because AI-2 receptors share homology with ribose-binding proteins, with ribose acting as a receptor antagonist on AI-2 receptors (29).

\section{The influence of QS in bacterial biofilms}

Several traits in bacterial biofilms are regulated via autoinducers. Approximately $15-20 \%$ of the biofilm volume is covered by bacterial colonies, while the rest is an extracellular polymeric substances (EPS) matrix. In other words, the colonies are embedded consist of a mixture of various natural polymers, mainly polysaccharides, and a variety of proteins, glycoproteins, glycolipids, and nucleic acids (30). A study by Frederick and friends reported that low EPS producing biofilm contains a higher cell population than high-EPS producing biofilm. Interestingly, they also concluded that the QS is used as a signal for the biofilm to switch from colonization mode to a protection mode (31). This might suggest the impact of QS on the regulation of biofilm occupancy and composition.

\section{Biofilm development}

Biofilms development involves stages of the microbial developmental process. There are five major stages of the biofilm development process, which include initial attachment, irreversible attachment, maturation I, maturation II and finally, dispersion stage (32; Fig. 1 a). Bacterial cells in dental plaque have been shown to develop the biofilms in an organized manner, initiated by the attachment of pioneer species followed by other colonizing species. Each microorganism alters the environment, which allows for successful community development.

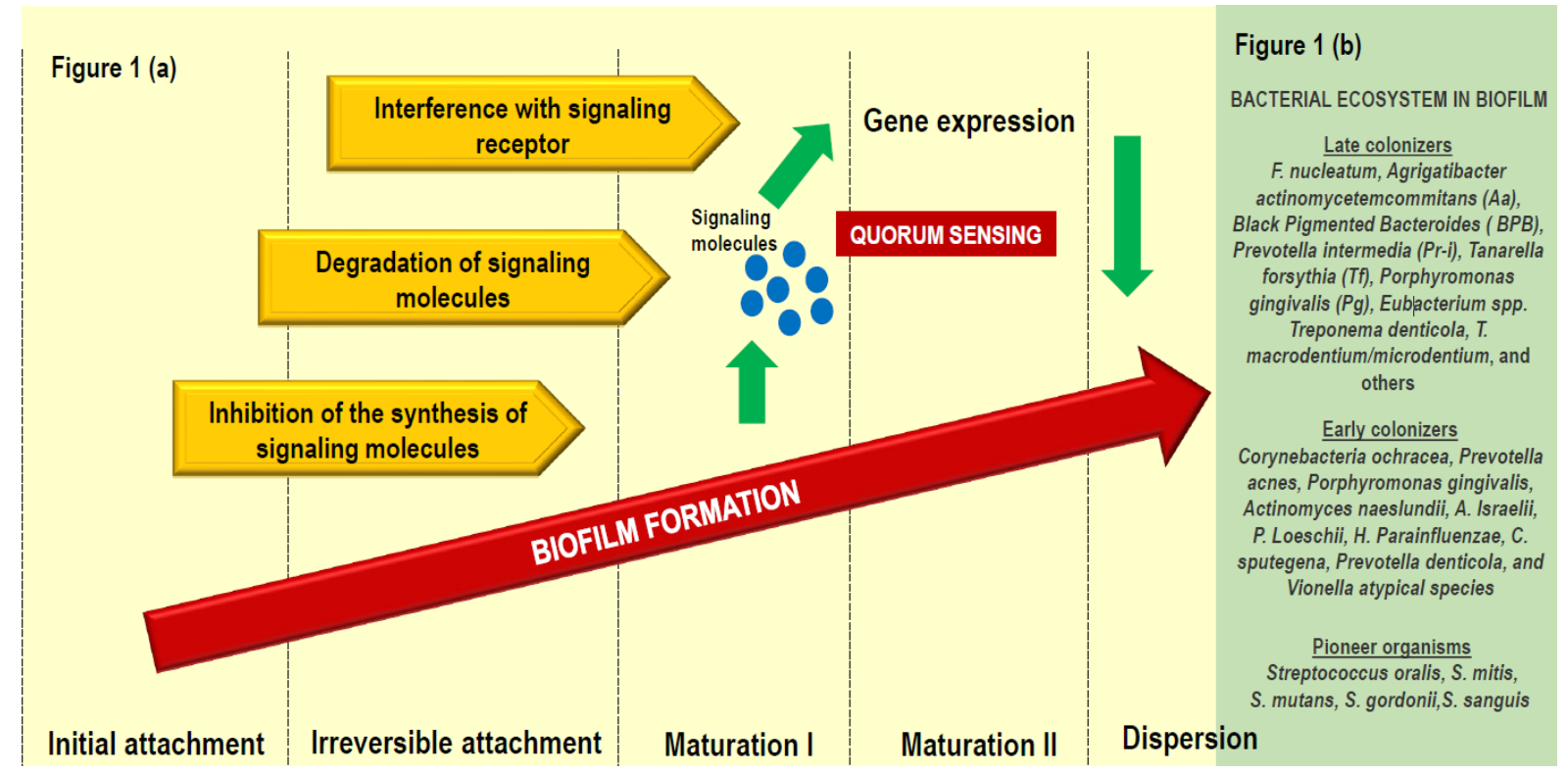

Fig. 1: (a) Schematic diagram of the biofilm formation stages and the interruption of QS systems together with identified bacterial ecosystems in biofilm. (b) Bacterial ecosystems in biofilm. Three different types of colonizers during biofilm formation in the oral cavity (Adapted from 33).

A specific bacterial ecosystem in the biofilm of a dental plaque consists of pioneer organisms, early colonizers, and late colonizers as shown in Figure 1 (b). Attachment on the tooth is the initial phase, the initial pioneer organisms include Streptococcus oralis, Streptococcus mitis, Streptococcus mutans, Streptococcus gordonii, and Streptococcus sanguis. Later, this group of bacterial and host molecules immediately coats the enamel surface of teeth followed by tooth eruption. At this stage, they play the role of the source of receptors for dental plaque's primary colonizers. Various substances such as mucins, agglutinins, proline-rich proteins (PRPs), phosphate-rich proteins (statherin), and alpha-amylase might act as the receptors for the primary colonizer
(34). They help bacteria species occupy space and gain an advantage in later competition with other species. Streptococci spp. represent $60-90 \%$ of these colonizers (35).

The early colonizers develop a biofilm by autoaggregation and coaggregation activity (36). Coaggregation structures built in a functional organization of bacterial plaque and different morphologic forms. The aerobic environment will change to facultative anaerobic when the attached bacteria multiply, developing a mature biofilm with microorganisms species and secreting an extracellular matrix (36). Other early colonizers include Actinomyces spp., Capnocytophaga spp., Eikenella 
spp., Haemophilus spp., Prevotella spp., Propionibacterium spp., and Veillonella spp (34). Fusobacterium nucleatum is the primary microbial organism, which acts as a significant connection in the network of attachment for the whole slew of early and later colonizers. Late colonizers attaching to $F$. nucleatum include $A$. actinomycetemcomitans, $P$. intermedia, $P$. gingivalis, Eubacterium spp., $T$. denticola, and others (34).

Biofilm activity plays an essential role in various microbial infections such as dental caries, periodontitis, otitis media, musculoskeletal infections, biliary tract infections, osteomyelitis, necrotizing fasciitis, bacterial prostatitis, native valve endocarditis, melioidosis, cystic fibrosis pneumonia, and peri-implantitis (37). In periodontal disease, gums' impartiality from teeth due to inflammatory responses to dental plaques is started by biofilm development on teeth surfaces by combining pathogenic and nonpathogenic bacterial species. The biofilm activity can be interrupted via inhibition of the QS activity. The inhibition of QS is commonly referred to as quorum quenching (QQ).

\section{Role of AI-2 in biofilm formation}

The AI-2 plays a significant role in the development of subgingival biofilm, which is composed of mostly Gram-negative anaerobes (38). The intra- and interspecies interaction among the periodontal pathogen in the human oral cavity might require the QS system to maintain their survival. The role of QS in the biofilm formation of periodontal pathogens was inhibited by D-galactose, which function as an AI-2 inhibitor (38). The D-galactose binding protein (Gbp) has a high sequence similarity with the AI-2 interacting protein in A. actinomycetemcomitans, ribose binding protein (RbsB) (38). A. actinomycetemcomitans are reported to possess a luxS-dependent signal circuit and secretes a high AI-2 like signal in the early and midexponential phase of the growth of the cell. Moreover, A. actinomycetemcomitans luxS synthesizes a signal that able to modulate the expression of luxS-regulated genes in $P$. gingivalis. Thus, suggesting that the interaction of these two periodontal pathogen species is conserved. The expression of $A$. actinomycetemcomitans leukotoxin is affected by AI2 and increases several-fold in early-log-phase cells after exposure to conditioned medium from recombinant Escherichia coli cultures expressing luxS (20).

\section{CONCLUSION}

QS activity is essential in the pathogenesis of the periodontal disease since the system is relates with the biofilm formation activity and the leukotoxin production in A. actinomycetemcomitans. Since application of QS activity as an alternative treatment for periodontal disease is still in the research stage, and more research is needed to prove the mechanism's details. For instance, the study of plants or bacterial extracted products that can inhibit QS in periodontal pathogens might provide new ideas and knowledge to understand the mechanism. Based on the previous findings and reports, there are QS possibilities in pathogenic bacteria to be influenced by probiotic lactobacillus. It is highly recommended that if further studies are performed on those species. It will potentially impact oral health and care by acting as an alternative treatment for periodontal pathogen infections. Modulating the QS system method as an approach against an infection of the pathogen might be a novelty and indirectly provides a counteraction solution to antibiotic resistance issues.

\section{ACKNOWLEDGEMENT}

This study is part of the research funded by the Fundamental Research Grants Scheme (FRGS) FRGS/1/2017/SKK06/UNISZA/02/1.

\section{CONFLICT OF INTEREST}

Authors declare no conflict of interest.

\section{REFERENCES}

1. Nazir, M. A. Prevalence of periodontal disease, its association with systemic diseases and prevention. Int $\mathrm{J}$ Heal Sci [Internet]. 2017; 11(2): 72-80. Available from: https://www.ncbi.nlm.nih.gov/pubmed/28539867

2. Newman, M. G., Socransky, S. S., Savitt, E. D., Propas, D. A. Crawford A. Studies of the microbiology of periodontosis. J Periodontol. 1976;47: 373-379.

3. Triantafyllia, V., Georgios, T. Periodontal diseases in children and adolescents affected by systemic disorders - a literature review. Int J Oral Dent Heal [Internet]. 2018; Available from: https://clinmedjournals.org/articles/ijodh /international-journal-of-oral-and-dental-health-ijodh-4055.pdf

4. Mahdizade-ari, M., Pourhajibagher, M., Bahador, A. Changes of microbial cell survival, metabolic activity, efflux capacity, and quorum sensing ability of Aggregatibacter actinomycetemcomitans due to antimicrobial photodynamic therapy-induced bystander effects. Photodiagnosis Photodyn Ther [Internet]. 2019; Available from: https://pubmed.ncbi. nlm.nih.gov/31026616/

5. Nørskov-Lauritsen, N., Kilian, M. Reclassification of Actinobacillus actinomycetemcomitans, Haemophilus aphrophilus, Haemophilus paraphrophilus and Haemophilus segnis as Aggregatibacter actinomycetemcomitans gen. nov., comb. nov., Aggregatibacter aphrophilus comb. nov. and Aggregatibacter. Int J Syst Evol Microbiol [Internet]. 2006; 56(9): 2135-2146. Available from: https://pubmed. ncbi. nlm.nih.gov/16957111/

6. Perry, M. B., Maclean, L. M., Brisson, J. R., Wilson, M. E. Structures of the antigenic O-polysaccharides of lipopolysaccharides produced by Actinobacillus actinomycetemcomitans serotypes a, c, d and e. Eur J Biochem [Internet]. 1996; 242(3): 682-688. Available from: https://febs.onlinelibrary.wiley.com/doi/full/10.1111/j.14321033.1996.0682r.x

7. Höglund-Åberg, C., Haubek, D., Kwamin, F., Johansson, A., Claesson, R. Leukotoxic activity of Aggregatibacter actinomycetemcomitans and periodontal attachment loss. PLoS One. 2014; 9(8).

8. Li, Y., Shibata, Y., Zhang, L., Kuboyama, N., Abiko, Y. Periodontal pathogen Aggregatibacter actinomycetemcomitans LPS induces mitochondriadependent-apoptosis in human placental trophoblasts. Placenta. 2011; 32(1): 11-19. 
9. Sosroseno, W., Bird, P. S., Seymour, G. J. Nitric oxide production by a human osteoblast cell line stimulated with Aggregatibacter actinomycetemcomitans lipopolysaccharide. Oral Microbiol Immunol. 2009; 24(1): 50-55.

10. Aida, Y., Kukita, T., Takada, H., Maeda, K., Pabst, M. J. Lipopolysaccharides from periodontal pathogens prime neutrophils for enhanced respiratory burst: differential effect of a synthetic lipid a Precursor IVA(LA-14-PP). J Periodontal Res [Internet]. 1995; Available from: https://pubmed.ncbi. nlm.nih.gov/7539837/

11. March, J. C., Bentley, W. E. Quorum sensing and bacterial cross-talk in biotechnology. Curr Opin Biotechnol [Internet]. 2004; 15(5): 495-502. Available from: https://www.science direct.com/science/article/abs/pii/S0958166904001193?via \%3Dihub

12. Plančak, D., Musić, L., Puhar, I. Quorum sensing of periodontal pathogens. Acta Stomatol Croat [Internet]. 2015; Available from: https://www.ncbi.nlm.nih.gov/pmc/articles/ PMC4993591/

13. Papenfort, K., Bassler, B. L. Quorum sensing signal-response systems in Gram-negative bacteria [Internet]. Nature Reviews Microbiology 2016 p. 576-588. Available from: https://www.nature.com/articles/nrmicro.2016.89

14. Bassler, B. L. How bacteria talk to each other: Regulation of gene expression by quorum sensing [Internet]. Current Opinion in Microbiology. 1999. Available from: https://www.sciencedirect.com/science/article/abs/pii/S1369 527499000259?via\%3Dihub

15. Bassler, B. L., Losick, R. Bacterially speaking. Cell [Internet]. 2006; 125(2): 237-246. Available from: https://www.ncbi.nlm.nih.gov/pubmed/16630813

16. Verbeke, F., De, C. S., Debunne, N., Janssens, Y., Wynendaele, E., Van-de, W. C. et al., Peptides as quorum sensing molecules: Measurement techniques and obtained levels in vitro and in vivo [Internet]. Frontiers in Neuroscience. 2017. Available from: https://www.frontiersin .org/articles/10.3389/fnins.2017.00183/full

17. Sudheer, Y., Kamalesh, B., Siddharth, S., Indra, G., Swetha, R.K. Quorum sensing inhibition, relevance to periodontics. J Int Oral Heal [Internet]. 2015; 7: 67-69. Available from: https://www.researchgate.net/publication/272843218_Quoru m_Sensing_Inhibition_Relevance_to_Periodontics

18. Antunes, L. C. M., Ferreira, R. B. R., Buckner, M. M. C., Finlay, B. B. Quorum sensing in bacterial virulence [Internet]. Microbiology. 2010. Available from: https://www.microbiologyresearch.org/content/journal/micr o/10.1099/mic.0.038794-0\#tab2

19. Bachtiar, E. W., Bachtiar, B. M., Jarosz, L. M., Amir, L. R., Sunarto, H., Ganin, H. et al., AI-2 of Aggregatibacter actinomycetemcomitans inhibits Candida albicans biofilm formation. Front Cell Infect Microbiol [Internet]. 2014 [cited 2020 Aug 5]; 4(JUL): 1-8. Available from: https://www. frontiersin.org/articles/10.3389/fcimb.2014.00094/full

20. Fong, K. P., Chung, W. O., Lamont, R. J., Demuth, D. R. Intra- and interspecies regulation of gene expression by Actinobacillus actinomycetemcomitans LuxS. Infect Immun. 2001.

21. Frias, J., Olle, E., Alsina, M. Periodontal pathogens produce quorum sensing signal molecules. Infect Immun [Internet]. 2001; Available from: https://www.ncbi.nlm.nih.gov/pmc /articles/PMC98305/

22. Szymon, P. S., Zhi-Luo, D., Jurgen, T., Michael, J., Sabin, B., Manfred, R., Helena, S., Irene, W-D. Quorum sensing of Streptococcus mutans is activated by Aggregatibacter actinomycetemcomitans and by the periodontal microbiome. BMC Genomics [Internet]. 2017 Mar 20 [cited 2021 Jan 26]; 18(1). Available from: https://bmcgenomics.biomedcentral .com/articles/10.1186/s12864-017-3618-5

23. Fong, K. P., Gao, L., Demuth, D. R. luxS and arcB control aerobic growth of Actinobacillus actinomycetemcomitans under iron limitation. Infect Immun [Internet]. 2003; 71(1): 298-308. Available from: https://www.ncbi.nlm.nih.gov/ pubmed/12496179
24. Shao, H., Lamont, R. J., Demuth, D. R. Autoinducer 2 is required for biofilm growth of Aggregatibacter (Actinobacillus) actinomycetemcomitans. Infect Immun [Internet]. 2007; 75(9): 4211-4218. Available from: https://www.ncbi.nlm.nih.gov/pubmed/17591788

25. Novak, E. A., Shao, H. J., Daep, C. A., Demuth, D. R. Autoinducer-2 and QseC control biofilm formation and in vivo virulence of Aggregatibacter actinomycetemcomitans. Infect Immun [Internet]. 2010 [cited 2021 Jan 26]; 78(7): 2919-2926. Available from: https://iai.asm.org/content/78/7 12919

26. Bachtiar, E. W., Bachtiar, B. M. Effect of cell-free spent media prepared from Aggregatibacter actinomycetemcomitans on the growth of Candida albicans and Streptococcus mutans in co-species biofilms. Eur J Oral Sci [Internet]. 2020; Available from: https://onlinelibrary .wiley.com/doi/abs/10.1111/eos. 12725

27. Juárez-Rodríguez, M. D., Torres-Escobar, A., Demuth, D. R. ygiW and qseBC are co-expressed in Aggregatibacter actinomycetemcomitans and regulate biofilm growth. Microbiol (United Kingdom) [Internet]. 2013; Available from: https://pubmed.ncbi.nlm.nih.gov/23519160/

28. Weigel, W. A., Demuth, D. R. QseBC, a two-component bacterial adrenergic receptor and global regulator of virulence in Enterobacteriaceae and Pasteurellaceae. Molecular Oral Microbiology. 2016.

29. James, D., Shao, H., Lamont, R. J., Demuth, D. R. The Actinobacillus actinomycetemcomitans ribose binding protein RbsB interacts with cognate and heterologous autoinducer 2 signals. Infect Immun [Internet]. 2006; 74(7): 4021-4029. Available from: https://www.ncbi.nlm.nih.gov /pubmed/16790775

30. Flemming, H.C., Neu, T.R., Wozniak, D.J. The EPS matrix: the "house of biofilm cells." J Bacteriol [Internet]. 2007; 189(22): 7945-7. Available from: https://www.ncbi.nlm. nih.gov/pubmed/17675377

31. Frederick, M. R., Kuttler, C., Hense, B. A., Eberl, H. J. A mathematical model of quorum sensing regulated EPS production in biofilm communities. Theor Biol Med Model. 2011; 8(1): 1-29.

32. Monroe, D. Looking for chinks in the armor of bacterial biofilms. PLoS Biol [Internet]. 2007;5(11): e307. Available from: https://www.ncbi.nlm.nih.gov/pubmed/18001153

33. Zhang, W., Li, C. Exploiting quorum sensing interfering strategies in gram-negative bacteria for the enhancement of environmental applications. Front Microbiol. 2016;

34. Kolenbrander, P. E., Andersen, R. N., Blehert, D. S., Egland, P. G., Foster, J. S., Palmer, Jr. R. J. Communication among oral bacteria. Microbiol Mol Biol Rev [Internet]. 2002; 66(3): 486-505. Available from: https://www.ncbi.nlm.nih.gov/ pubmed/12209001

35. Nyvad, B., Kilian, M. Microbiology of the early colonization of human enamel and root surfaces in vivo. Scand J Dent Res [Internet]. 1987; 95(5): 369-80. Available from: https://www.ncbi.nlm.nih.gov/pubmed/3477852

36. Chandki, R., Banthia, P., Banthia, R. Biofilms: A microbial home. J Indian Soc Periodontol [Internet]. 2011; 15(2): 1114. Available from: https://www.ncbi.nlm.nih.gov/pubmed 121976832

37. Socransky, S. S., Haffajee, A. D. Dental biofilms: difficult therapeutic targets. Periodontol 2000 [Internet]. 2002; 28: 1255. Available from: https://www.ncbi.nlm.nih.gov/pubmed $/ 12013340$

38. Ryu, E. J., Sim, J., Sim, J., Lee, J., Choi, B. K. D-Galactose as an autoinducer 2 inhibitor to control the biofilm formation of periodontopathogens. J Microbiol [Internet]. 2016. 